\title{
Editorial
}

\section{Crônica de uma catástrofe anunciada}

\author{
I Kenneth R. de Camargo Jr. |
}

Há alguns meses, já fazíamos advertência sobre a grave ameaça representada pela (então) Proposta de Emenda Constitucional que congelava por vinte anos o orçamento da União, admitindo apenas correção pela inflação (CAMARGO JR, 2016). A aprovação dessa proposta, transformada na EC 95/2016, torna ainda mais difícil reverter o processo de desmonte de direitos ora em curso, já que sua reversão necessitará também de quórum qualificado no Congresso, o que não parece possível sem modificação dramática do quadro presente.

Essa EC é o exemplo mais acabado de uma política de "austeridade", de cortes em gastos públicos, como estratégia para fazer frente a crises econômicas. Diversos países do mundo têm recorrido a este tipo de política como recurso para fazer frente à continuada crise da economia global, disparada após o estouro da "bolha" hipotecária nos Estados Unidos em 2008.

Embora as repercussões de crises econômicas na saúde não sejam lineares, o fator determinante parece ser não a crise em si mas o tipo de resposta política adotado por diversas nações. E, a julgar pelos antecedentes históricos (STUCKLER; BASU, 2013), ou o que ocorre no momento na Europa (KARANIKOLOS et al., 2013; KENTIKELENIS et al., 2014; McKEE et al., 2012; QUAGLIO et al., 2013), devemos esperar uma deterioração ainda maior da saúde da população, bem como da capacidade do SUS de dar conta dos incrementos dos agravos de saúde (ROSSI; DWECK, 2016).

A lógica subjacente a esse tipo de política é ironizada por Paul Krugman, que a descreve como sendo uma espécie de fábula moral; economias "mal comportadas" precisam mostrar que estão dispostas a expiar seus pecados com pesados castigos autoinfligidos para que a "fada da confiança" as abençoe e os fluxos financeiros voltem a jorrar (KRUGMAN, 2015). Para além desse aspecto quase caricatural, há um problema ainda mais grave: a história mostra que essa estratégia falhou toda vez que foi empregada (BLYTH, 2013). No momento em que o Brasil necessita estimular a economia e reduzir a carga que a taxa de juros impõe, a política governamental marcha aceleradamente na direção contrária (PIRES, 2017). 
Em suma, está-se impondo um sacrifício injustificável à população brasileira, em especial aos mais vulneráveis, em nome de uma política econômica que não só não tem evidência empírica de ter sido bem-sucedida, como historicamente se mostrou mais do que ineficaz, destrutiva. Esse ultraje se tornou possível pela participação ativa de diversos atores, entre os quais destacamos os meios de comunicação de massa brasileiros (FERREIRA et al., 2017).

Não podemos silenciar nossas vozes frente a tamanho ataque ao direito constitucional à saúde, duramente conquistado após anos de luta e resistência. Como pesquisadores, profissionais de saúde, professors e cidadãos, temos o dever de lutar pela reversão dessa política daninha e injustificável. Lembremo-nos do chamado de Stéphane Hessel, veterano combatente da Resistência Francesa, que em seu manifesto de 2010, "Indignez-vous!" (Indignai-vos!) conclamava por "uma verdadeira revolta pacífica contra os meios de comunicação de massa que não oferecem outro horizonte para a nossa juventude que o consumo de massa, o desprezo pelos mais fracos e pela cultura, a amnésia generalizada e a competição desbragada de todos contra todos." (HESSEL, 2010, p. 13).

\section{Referências}

BLYTH, M. Austerity: the history of a dangerous idea. Oxford (UK): Oxford University Press, 2013.

CAMARGO JR, K. R. Austeridade faz mal à saúde. Physis: Revista de Saúde Coletiva. Rio de Janeiro, v. 26, n. 4, p. 1091-1096, 2016.

FERREIRA, S. et al. A (des)informação da mídia na economia. Jornal dos Economistas, n. 331, p. 12-13, 2017.

HESSEL, S. Indignez-vous! Paris: Indigene Editions, 2010.

KARANIKOLOS, M. et al. Financial crisis, austerity, and health in Europe. The Lancet, v. 381, n. 9874, p. 1323-1331, 2013.

KENTIKELENIS, A. et al. Greece's health crisis: from austerity to denialism. The Lancet, v. 383, n. 9918, p. 748-753, 2014.

KRUGMAN, P. The austerity delusion. The Guardian, v. 29, 2015.

McKEE, M. et al. Austerity: a failed experiment on the people of Europe. Clinical medicine, v. 12, n. 4, p. 346-350, 2012.

PIRES, M. C. Política econômica e estabilização: uma breve análise da recessão brasileira. Brazilian Keynesian Review, v. 2, n. 2, p. 247-251, 2017.

QUAGLIO, G. et al. Austerity and health in Europe. Health policy, v. 113, n. 1, p. 13-19, 2013. ROSSI, P.; DWECK, E. Impacts of the new fiscal regime on health and education. Cadernos de Saúde Pública. Rio de Janeiro, v. 32, n. 12, 2016.

STUCKLER, D.; BASU, S. The body economic: why austerity kills. New York: Basic Books, 2013. 